University of Rhode Island

DigitalCommons@URI

Open Access Master's Theses

2020

\title{
AN EXAMINATION OF GOLF MAGAZINES FOR HEALTH BELIEF MODEL APPLICATIONS AND SKIN CANCER PROTECTION ADVICE
}

Beth A. Bailey

University of Rhode Island, babpr3b@cox.net

Follow this and additional works at: https://digitalcommons.uri.edu/theses

\section{Recommended Citation}

Bailey, Beth A., "AN EXAMINATION OF GOLF MAGAZINES FOR HEALTH BELIEF MODEL APPLICATIONS AND SKIN CANCER PROTECTION ADVICE" (2020). Open Access Master's Theses. Paper 1922.

https://digitalcommons.uri.edu/theses/1922

This Thesis is brought to you for free and open access by DigitalCommons@URI. It has been accepted for inclusion in Open Access Master's Theses by an authorized administrator of DigitalCommons@URI. For more information, please contact digitalcommons-group@uri.edu. 
AN EXAMINATION OF GOLF MAGAZINES FOR HEALTH BELIEF MODEL APPLICATIONS AND SKIN CANCER PROTECTION ADVICE

\section{BY}

BETH A. BAILEY

A THESIS SUBMITTED IN PARTIAL FULFILLMENT OF THE

REQUIREMENTS FOR THE DEGREE OF

MASTER OF ARTS

IN

COMMUNICATIONS STUDIES

UNIVERSITY OF RHODE ISLAND 


\section{MASTER OF ARTS THESIS}

OF

BETH A. BAILEY

\section{APPROVED:}

Thesis Committee:

$\begin{array}{ll}\text { Major Professor: } & \text { Yinjiao Ye } \\ & \text { Norbert Mundorf } \\ & \text { Ping Xu } \\ & \text { Brenton DeBoef } \\ & \text { DEAN OF THE GRADUATE SCHOOL }\end{array}$

UNIVERSITY OF RHODE ISLAND

2020 


\begin{abstract}
Skin cancer rates are elevated among men, especially men who participate in outdoor sports, such as golf. Male golfers who play regularly are particularly susceptible to skin cancers because of the length of ultraviolet radiation exposure during game time, lack of adequate skin protection, plus their cumulative lifetime exposure is higher than non-golfers. Drawing on the health belief model, the purpose of the research was to analyze golf magazines from two decades for editorial content that communicates the increased risk of skin cancer for male golfers as well as protective measures they can undertake to prevent ultraviolent solar radiation exposure, the primary cause of skin cancers. The study reviewed 20 years of content (1999-2019) for health belief model constructs and interviewed male golfers about their beliefs regarding their skin cancer risks and how they learned to protect their skin. The editorial coverage lacked explanations about why preventative measures are essential and too brief to explain the risks in depth. Photos and illustrations of golfers do not reflect golfer identities. Health interventionists can look to golf magazines as a channel for educational campaigns for men at risk for skin cancer.
\end{abstract}




\section{ACKNOWLEDGEMENTS}

I would like to acknowledge everyone at the University of Rhode Island who played a role in my academic accomplishments. My major professor, Yinjiao Ye, Ph.D, Director of Graduate Studies, Department of Communication Studies, provided thoughtful guidance and encouragement during all phases of thesis development. She was always available for a consult and patient with me as I learned to navigate the unfamiliar. My sincere gratitude for sharing your time and knowledge with me as I fulfilled this much desired academic milestone.

My committee members — Norbert Mundorf, Ph.D. Interim Director, Harrington School of Communication and Media, and Ping Xu, Ph.D., Associate Professor, Department of Political Science - deserve my thanks for your advice, support, and guidance. Julie Coiro, Ph.D., Associate Professor, Reading Education, deserves my thanks for her time in serving in the oversight role on my committee.

During the disruption to the thesis cycle presented by the pandemic shut-down, each member of my committee, as well as Brenton DeBoef, Ph.D., Dean, Graduate School, demonstrated commendable flexibility and accommodation in order to keep this project on track. I am very grateful.

Mary MacDonald, M.Lis., Head of Instruction, Public Services Department, University Libraries, is greatly appreciated for her tutorial session of the university's library databases as well as propelling my magazine research forward. When I was unable to visit the library for materials not available online, Andrée Rathemacher, Head of Acquisitions, University Libraries and Peter Larsen, Head of Reference, University Libraries, pointed me in the direction of the InterLibrary Loan program. A special nod to 
Stacy Carrasco, M.S., Enrollment Services Representative, for her kind instructions on my least favorite task: forms. Thank you all.

To the golfers who shared their experiences for the purpose of this study, I appreciate your willingness to help and your candor.

My dear sister, Andrea Hainey-LaPierre, Ph.D., accepted the task of providing a reliability test for my coding without hesitation, and I greatly appreciate your time and thoughtfulness. A special thank you to Brandon Donohoe, M.A., for his early coding test in the proposal stage.

Thank you Amy Grzybowski, of the R.I. Office of the Postsecondary Commissioner, for your unflagging support for my professional development ambitions. I'm ever grateful.

I would also like to express my eternal love and thankfulness to my amazing husband, Bob and my wonderful son, Andrew, for supporting me throughout this journey. 


\section{TABLE OF CONTENTS}

ABSTRACT

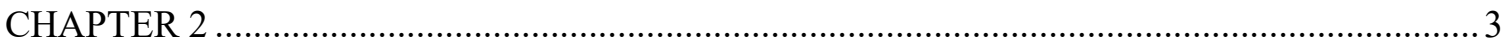

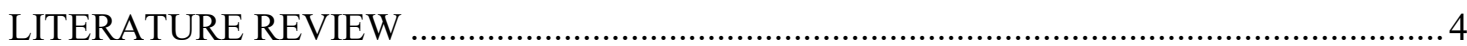

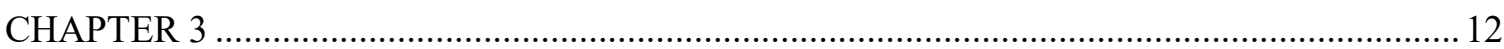

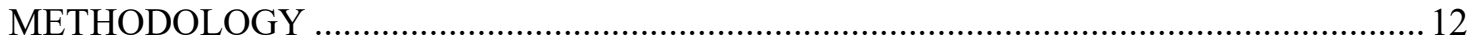

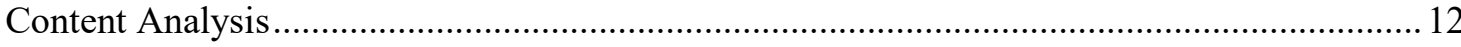

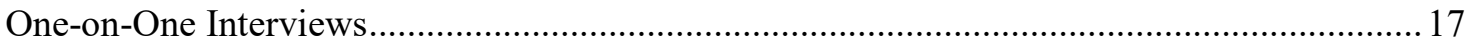



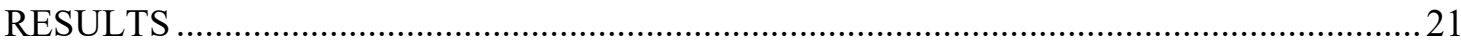

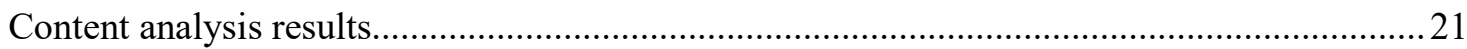

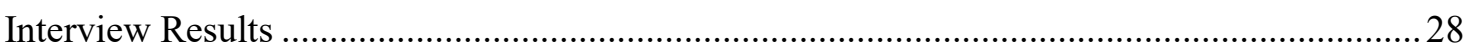

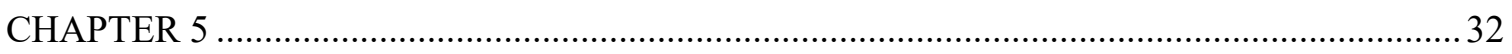

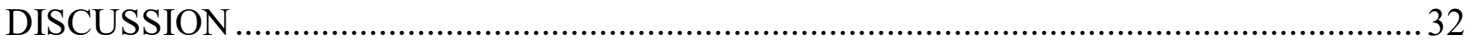

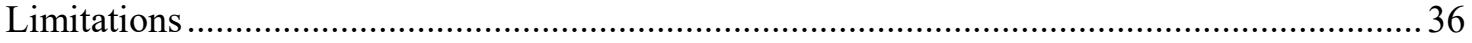

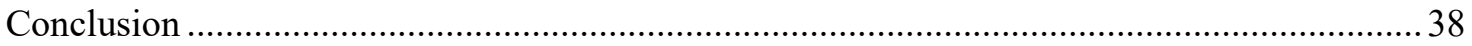

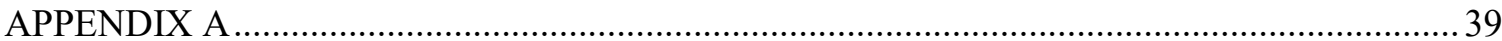

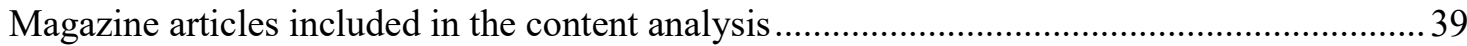

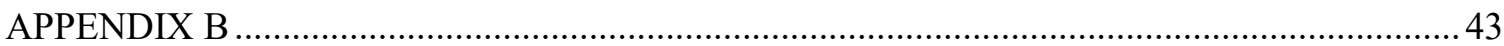

Sample images from golf magazines analyzed for skin cancer content in golf magazines. ...... 43

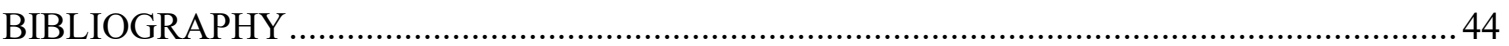




\section{LIST OF TABLES}

Table 1 Magazine details and number of skin cancer and solar protection content published from 1999 to 2019

Table 2 Coding scheme for magazine content by health belief model constructs and with examples

Table 3 Examples of interview questions

Table 4 Health belief model construct frequencies 


\section{CHAPTER 1}

\section{INTRODUCTION}

In 2014, the United States Surgeon General issued a report on skin cancer, stating that the rates continue to rise, affect more than 5 million Americans annually, cost more than $\$ 8$ billion to treat, and take the lives of 9,000. Two groups identified with higher risks than average are men and athletes. Certainly, frequently participating in exercise outdoors is beneficial to health but less so when the athletes - professional and amateur alike - expose themselves excessively to UV solar radiation, the most primary cause of skin cancer.

A cancer diagnosis can bring emotional, physical, financial and psychological harm to individuals. Although medical advancements often extend survival rates and make treatments shorter and less harsh, prevention by way of avoiding carcinogens is preferable. Mass media aid medical experts in educating the public about carcinogenics and their effects on humans. Articles feature information, without medical jargon, to help readers understand the vast varieties of cancers, the known and suspected causes, surgical and oncological medical treatments, and prevention tactics. Educating people to avoid carcinogens intentionally results in more healthy, less painful lives while alleviating the burden on the medical ecosystem treating cancers.

Because of the complexity of human behavior and the influences upon it throughout a lifetime, a simple approach to persuade people to adopt healthy practices does not exist. Identifying subsets of individuals and examining their exposures to 
carcinogens, and then devising communications that will effectively convey information that will help them make lifestyle adjustments is a key element to prevention.

Prior research in mass media sources has focused on men's and women's magazines and national newspapers. The information may have been helpful to all readers in many demographic categories, but the broad messaging hasn't been tailored to this niche audience identified as highly susceptible to skin cancer. Researchers to date have not examined skin cancer educational material in golf magazines, a mass media specialty format with high readership among male golfers. A review of editorial content pertaining to skin cancer for the scope, frequency, and relevance of information will aid in devising messaging that addresses weaknesses and gaps.

To this end, this research will analyze editorial content in golf magazines pertaining to past messaging about skin cancer and interview male golfers about their impressions about the content, how it has affected their skin protection beliefs and behaviors; and their receptiveness to more skin cancer content in golf magazines. Because product advertising is created by manufacturers and sales benefit their businesses, advertising messages carry bias and are not considered as credible as content curated by neutral sources, such as reporters and columnists. Therefore, the current study does not analyze advertising content in golf magazines.

I hope this research will shed light on the design of a communications campaign specifically for male golfers about their unique challenges related to skin cancer disease, and thus can help to reduce incidence among this target audience identified by data as at higher risk. Male golfers, like many Americans, consume large amounts of mass media and audience segmentation and microtargeting tailored messages to them is a common 
campaign practice - in fundraising, elections, consumer marketing, public advocacy, and many more sectors. 


\section{CHAPTER 2}

\section{LITERATURE REVIEW}

When detected early and treated appropriately, persons with skin cancer have better survival rates (McWhirter \& Hoffman-Goetz, 2016). Because ultraviolet radiation is a carcinogen, restricting exposure reduces one's chances of contracting skin cancer (Dixon, Warne, Scully, Dobbinson, and Wakefield, 2014). According to medical experts, the best way to reduce exposure is avoidance, covering skin with clothing and hats when outdoors, applying sunscreen, and seeking shade (Anderson et al., 2017; Dixon et al., 2008; Heneghan et al., 2007; McWhirter \& Hoffman-Goetz, 2015). The most protection is offered by employment of all four behaviors concurrently, but few adults practice more than one when preparing for outdoor activities (Bleakley et al., 2018). None is rated higher than the others, yet the application of sunscreen has received the most attention in media and public health campaigns (Anderson et al., 2017; Bleakley et al., 2018; Dixon et al., 2008). Promotion of sunscreen use garners the highest frequency of all protection behaviors in news and magazine articles, but details about how to use the product successfully are often neglected (Cokkinides et al., 2012).

Lack of fully informed messaging about all of the protective measures translates to an ill-informed public about the deleterious, long-term effects of sunburn (Dixon et al., 2014). Over the course of decades, anti-sunburn, anti-tanning and self-protection multichannel media campaigns have increased awareness of the direct evidence connecting cancer and ultraviolet exposure, but people have not changed their behaviors to adopt the 
inexpensive and easy measures that will protect their skin from ultraviolet solar radiation (Barrett, Usher, Woods, and Conway, 2019; Parsons et al., 2018). America isn't the only country with rising rates of skin cancers: Australia has the highest rates in the world (Anderson et al., 2017; Barrett et al., 2019; Dixon et al., 2008; Dixon et al., 2014). Australian studies analyzing male adoption of ultraviolet radiation protective behaviors concluded that men can be convinced to change their behavior when it comes to adding multiple sun protections but it is difficult, especially for golfers (Dixon et al., 2008). Golfers and men may need targeted media messages about their unique risks (Office of the Surgeon General, 2014).

Skin cancer is a disease taking a toll disproportionately on men. While it is estimated by the American Academy of Dermatology that "melanoma will affect 1 in 27 men and 1 in 40 women in their lifetime," the mortality rate for men is much higher (American Academy of Dermatology, 2019; McWhirter \& Hoffman-Goetz, 2016). Men between the ages of 15 and 39 were " $55 \%$ more likely to die from melanoma" compared with women afflicted with melanoma at the same age (American Academy of Dermatology, 2019). Melanoma mortality rates have been on the rise since 1973, especially among men 35 and older (Geller et al., 2006; McWhirter \& Hoffman-Goetz, 2016). Repeated sunburns and cumulative lifetime exposure to ultraviolet radiation increases the risk for skin cancer (Matthews et al., 2018; McWhirter \& Hoffman-Goetz, 2016). Men's higher melanoma rates may be partially attributed to reduced levels of ultraviolet radiation protection behaviors (American Academy of Dermatology, 2019; Geller et al., 2006). Men may fall victim to the perils of skin cancer because of masculinity norms that frame their self-care and healthy activities as 'feminine' (Geller et 
al., 2006; Office of the Surgeon General, 2014) or from ignorance. Nearly half of men in America cannot identify that melanoma is skin cancer (Geller et al., 2006) despite the increased levels of information available in popular media (Heneghan et al., 2007) and from medical doctors. If men don't know the signs and symptoms of melanoma, their ability to detect it early impedes their health and further increases the likelihood that they will require more costly, more serious treatments (Geller et al., 2006).

Regardless of gender, skin cancer strikes athletes who engage in outdoor sports more frequently than that of the rest of the population (Downs et al., 2009). The heightened levels of ultraviolet radiation exposure over time contributes to their overall risk of developing skin cancer (Downs et al., 2009; Matthews et al., 2018; McWhirter \& Hoffman-Goetz, 2016). Scottish health researchers noted that "golf is associated with relatively more UVR exposure than other outdoor activities such as fishing, tennis, pool swimming, cricket, gardening, 'sun-worshipping' and sailing" (Matthews et al., 2018), and based on the cumulative exposure of extended play over active players' lifetimes is higher than non-golfers (Matthews et al., 2018). Men are less likely to use the combination of sunscreen application, clothing barriers, and shade-seeking behaviors (Bleakley et al., 2018). One study observing Australians' protective sun behaviors using clothing barriers over 20 years noted improvements in covering up with clothing except on golf courses (emphasis added) (Dixon et al., 2008).

Health Belief Model

The health belief model is a theory developed to explain and predict individual health behaviors. The paradigm looks at a person's beliefs in and confidence to adopt recommended health behaviors so as to thwart the threat of a disease or illness based on 
the belief in the effectiveness of those health behaviors. Developed by Hochbaum, Rosenstock and Kegels, a trio of 1950s-era social psychologists, to improve predicting and explaining health behaviors among individuals afflicted with tuberculosis (Gristwood, 2011), the health belief model "looks deeper into the relationship between an individual's confidence to take action (self-efficacy) if they perceive themselves to be susceptible to a condition, the identification of the potential severity (...), and evaluation of perceived benefits versus barriers" (Gristwood, 2011).

The six constructs to predict that health behavior are: risk susceptibility, risk severity, benefits to action, barriers to action, cues to action and self-efficacy (Glanz, Rimer, \& Viswanath, 2015). Briefly, perceived susceptibility is the individual's opinion about his or her risk of contracting a disease, illness, or condition (Glanz et al., 2010; Gristwood, 2011). Perceived severity is a construct that explains the beliefs individuals hold about the seriousness with which they regard a disease, illness, or condition as well as any of the negative effects of being stricken by it, such as death, physical pain, mental anguish, lost wages, and more (Glanz et al., 2010; Gristwood, 2011). Perceived barriers to taking actions that will prevent or mitigate advancement of a disease, illness, or condition are the social, tangible, psychological or emotional beliefs of people about why they cannot undertake recommended actions (Glanz et al., 2010; Gristwood, 2011). Examples of barriers are stigma, vanity, inconvenience, lack of motivation, cost, and fear. As a construct, self-efficacy explains that individuals must believe they are self-enabled to take actions needed to achieve positive results (Glanz et al., 2010; Gristwood, 2011). The application of the health belief model can help identify health behaviors associated with golfers and the drivers needed to shift their behaviors favorable to skin 
cancer protection, and intervention strategies targeting them can be developed and deployed (Geller et al., 2006). In this research, the perceived susceptibility construct pertains to information that explains the risk and likelihood of contracting skin cancer as well as the factors that influence the onset of skin cancer (e.g., golfers who don't use any protection are more likely to develop cancer). Information that would increase golfers' understanding of the seriousness of skin cancer and/or ultraviolet solar exposure as well as the medical treatments and long-lasting effects on health, well-being and appearance (e.g., scarring, lost wages, disfigurement) are pertinent. Perceived benefits are the results golfers would realize by undertaking preventative measures. For golfers, the perceived barriers construct provides understanding about why some men avoid consulting with medical experts about suspicious-looking moles or not wanting to be the only golfer applying sunblock. Self-efficacy is the belief and self-confidence that the golfers can conduct skin self-exams, inventory moles, look for changes in skin appearance, and consult with medical professionals about seriousness and future action. This is positive action to protect his skin and prevent skin cancer (Glatz, Rimer \& Viswanath, 2010). Media studies

Because the news and popular media are influential in public health education efforts, analysis of published content, topic frequency, and adherence to fact-based messaging is helpful to measure actual behavior changes that are influenced by targeted campaigns. Content analyses performed on editorial messaging in periodicals printing skin cancer articles can be instructional for prevention messaging. Researchers have inventoried popular men's and women's magazines for 11 years - before and after the issuance of a report "linking the connection between indoor tanning and skin cancer" 
(McWhirter \& Hoffman-Goetz, 2015), and after performing a content analysis found only a slight change in the narrative about encouraging sunscreen use. A year later, McWhirter \& Hoffman-Goetz chose 20 popular women's and men's magazines for a content analysis of skin cancer and tanning articles and the presence of health belief model constructs within the editorial and images, and noted weaknesses in model constructs in the imagery (McWhirter \& Hoffman-Goetz, 2016). Dixon et al.'s (2014) research, which analyzed content of two Australian daily newspapers, reviewed the agenda-setting activity by these influential news organizations.

There was a gap in the literature regarding the cumulative effects on behavior for readers exposed to multi-year news about the dangers of ultraviolet radiation exposure, so the researchers combined a readership survey with an editorial content analysis regarding tanning and sun protection information. They found that some attitudes and behaviors changed to be less pro-sun, but not all opinions were moved, especially among young adults (Dixon et al., 2014). Heneghan et al. (2007) analyzed New York Times editorial content over a 24-year period to look for trends in skin cancer mentions, noting there was only a small rise (Heneghan et al., 2007). The increases coincided with publicity regarding a celebrity/political figure skin cancer diagnosis announcement but failed to consistently share prevention information (Heneghan et al., 2007). Much of the literature focuses on indoor tanning and the rising risk among young women (Noar et al., 2015); skin cancer rates among populations by state (Parsons et al., 2018); or country (Barrett et al., 2019; Dixson et al, 2008; Dixon et al., 2014; Downs, Parisi and Schouten, 2011; Downs et al., 2009); how the media cover skin cancer prevention (McWhirter \& 
Hoffman-Goetz, 2015); and the influence of viral skin cancer photos on social media sites (Noar et al., 2018; Tang \& Park, 2017).

Researchers have identified that lackadaisical attitudes held by men about their own skin cancer risks (Barrett et al., 2019; Geller et al., 2006; McWhirter \& HoffmanGoetz, 2015) and their lack of self-protection (Bleakley et al., 2018; Barrett et al., 2019; Dixson et al, 2008; Holman et al., 2015; Matthews et al., 2018) has affected their skin cancer rates. Men who are weekly golfers can alter their risks of developing skin cancer based on golf tee times (Downs et al., 2009).There is a gap in the literature about how golfing specialty media (such as Golf Digest, Golf Magazine, and Golf World) communicate sun protection and skin cancer information to their audiences, especially men. Because golfers have a higher than average risk and men underestimate their skin cancer risks (Matthews et al., 2018), evaluating the content they consume in specialty golf media will help inform interventionists who design campaigns to address message weaknesses more directly and more appropriately for this audience at risk (Cokkinides et al., 2012). Developing messaging and interventions targeting "specific audiences" was a strategy within the U.S. Surgeon General's Call to Action to Prevent Skin Cancer report. Strategy 2A calls to "improve sun protection, especially among adult men" by emphasizing "wide-brimmed hats, protective clothing, and broad spectrum sunscreen ...when outdoors for extended periods." Also mentioned in that report's strategy was a recommendation to "improve communication about when and how to use sun protection" (Office of the Surgeon General, 2014, pp.50-51).

Readers of golf magazines skew heavily male. According to Golf Digest, the most read golf magazine, $82 \%$ of its subscriber base are male. Gathering information from this 
and other golf magazines about their skin cancer coverage, such as how frequently they publish articles about it, how comprehensive the articles are, and that types of advice they are providing, will help improve the creation of prevention messages for male golfers that will resonate with them and motivate behavior changes. Because golf magazines are not as popular among women golfers and women golfers do not have the same incidence of skin cancer as male golfers, the research will focus on male golfers. To that end, this research examined the following questions:

RQ1: To what extent is skin cancer protection covered by golfing magazines? RQ2: To what extent are golf magazines printing advice about the severity of skin cancer and men's susceptibility to it as well as acknowledging the barriers and benefits of avoidant and protective tactics?

It also endeavored to determine if vertical media (i.e., golf magazines) are sufficient in creating the momentous shift needed within this demographic in order to be effective over time. Asking men who golf if the information they read in golf magazines was informing them about their long-term and short-term ultraviolet radiation risks helped address the following question:

RQ3: Are male golfers following advice about skin cancer protection measures published in golf magazines?

While the association between recall of articles and the effect of learning and adopting behaviors would be difficult to draw from a study of this size and scope, the information gathered was examined for evidence of a relationship. 


\section{CHAPTER 3}

\section{METHODOLOGY}

In the course of this research, two methods were utilized. A content analysis of the most popular golfing magazines in the United States was performed to gather information about how well the topic of solar protection had been covered and for the presence of the health belief model in published content. Interviews were conducted with male golfers to gain insight about their ultraviolet solar protection practices and how they had been influenced to adopt these behaviors.

\section{Content Analysis}

Sample. The three golf magazines with the largest circulation figures in the U.S., as self-described in media sales kits, were selected for the content analysis: Golf Magazine, Golf Digest and Golf World. See Table 1 for circulation statistics and the number of relevant articles procured for the research. Qualifying content included articles, columns, editorials, opinions, letters to the editor, sidebars, health quizzes, photos, illustrations, cartoons, product reviews, and Q\&A. Advertising was excluded. 
Table 1 Magazine details and number of skin cancer and solar protection content published from 1999 to 2019

\begin{tabular}{|l|l|l|l|}
\hline Magazine & Circulation & $\begin{array}{l}\text { Number of } \\
\text { Articles }\end{array}$ & Number of Images \\
\hline $\begin{array}{l}\text { Golf } \\
\text { Magazine }\end{array}$ & $1,430,563$ & 15 & 13 \\
\hline Golf Digest & $1,663,571$ & 40 & 53 \\
\hline Golf World & 158,756 & 9 & 3 \\
\hline Total & $3,252,890$ & 64 & 69 \\
\hline
\end{tabular}

Note. Photographs were no longer available for some of the archived articles

Articles and images from the three magazines, dated from 1994 to 2019, were collected via acquisition of back issues, PDF copies from an interlibrary loan service, and full text versions from the University of Rhode Island library databases. Content was included if the key terms were contextually related to skin cancer prevention, or if the content demonstrated that skin cancer is a problem that needed to be avoided. For example, editorial that contained information about sunglasses must also have contained content about protecting eyes from solar damage or the sunglasses' ultraviolet protection status.

The search terms used in the Boolean search were: melanoma, basal cell carcinoma, squamous cell carcinoma, skin cancer, non-melanoma skin cancer, precancer, sunburn, tan*, ultra-violet radiation, sunscreen, sunblock, shade, sun*, solar, selfexam, derma*, mole, skincare, ABCDE (mole test), SPF, UVA, UVB, golf fashion, and sunglasses. Of the 72 articles identified in the 20-year period as relevant, 64 (88\%) were acquired. Five of the articles acquired lacked the accompanying photography but were 
analyzed because of the relevance of the written content, or the captions were deemed sufficient to grasp an understanding of the image(s). For example, a caption describing a bottle of sunblock and text that promoted wearing sunblock to protect golfers' skin qualified. Article searches that produced results for products, such as sunglasses, that did not also mention sun protection, UVR protection or similar, were excluded.

Coding Scheme. A coding scheme was constructed based on a preview of the sampled 64 articles, and operationalized the health belief model constructs as they pertained to ultraviolet solar radiation protection and skin cancer avoidance and treatment topics. Details of the coding scheme can be found in Table 2. The constructs used for the content analysis were: susceptibility of developing cancer or overexposure to ultraviolet solar radiation; severity of skin cancer and concomitant treatments; barriers to adopting preventive measures to avoid ultraviolet solar radiation exposure; the benefits of engaging in skin protection; and promotion of prevention and early skin cancer detection measures that could help golfers become more self-efficacious toward their skin health.

Content was coded by subcategory within the five constructs. Table 2 outlines the operational terms by construct and the subcategories. The unit of analysis was one article or one image. Multiple mentions of a construct in the same article were coded only once. For example, a feature-length story may include several mentions about sunblock as a benefit, but was recorded only once per article. An article entitled, "Head Cases," that presented a cheeky pseudo-psychoanalysis of an individual based on the choice of his preferred hat, was coded as a barrier. Only one hat of the 17 pictured featured a wide brim, the hat recommended as offering the most sun protection. The emasculating caption read, "Your wife made you wear it - 110 SPF sunscreen, too" ("Head Cases," 2018). The 
patronizing tone and the hat's location in the functional/boomer quadrant reinforced the bias that sunblock is feminine and ultraviolet protective hats are unfashionable and oldfashioned.

Table 2 Coding scheme for magazine content by health belief model constructs and with examples

\begin{tabular}{|c|c|c|c|}
\hline $\begin{array}{c}\text { Health belief } \\
\text { model } \\
\text { construct }\end{array}$ & $\begin{array}{l}\text { Description of } \\
\text { construct }\end{array}$ & Categories & Examples \\
\hline Susceptibility & $\begin{array}{l}\text { Information that } \\
\text { would explain the } \\
\text { risk and } \\
\text { likelihood of } \\
\text { getting skin } \\
\text { cancer as well as } \\
\text { the factors that } \\
\text { influence the } \\
\text { onset of skin } \\
\text { cancer. }\end{array}$ & $\begin{array}{l}\text { (1) Lifetime UV } \\
\text { exposure effects, } \\
\text { cumulative effects; } \\
\text { (2) Skin cancer } \\
\text { statistics (prevalence } \\
\text { of skin cancer rates } \\
\text { among men, mortality } \\
\text { rates, death rates); (3) } \\
\text { Mention about } \\
\text { incidence among pro } \\
\text { golfers; (4) Other. }\end{array}$ & $\begin{array}{l}\text { "One out of every five } \\
\text { Americans (one in } \\
\text { three Caucasians) will } \\
\text { develop some form of } \\
\text { skin cancer in their } \\
\text { lifetime. Every } \\
\text { dermatologist we } \\
\text { spoke with thinks the } \\
\text { odds are even worse } \\
\text { for golfers." ("Burned } \\
\text { to a Crisp" 2008) }\end{array}$ \\
\hline Severity & $\begin{array}{l}\text { Information that } \\
\text { would increase } \\
\text { the understanding } \\
\text { of perceived } \\
\text { seriousness of } \\
\text { skin cancer or } \\
\text { UV solar } \\
\text { exposure as well } \\
\text { as the treatments } \\
\text { and long-lasting } \\
\text { effects on health, } \\
\text { well-being and } \\
\text { appearance. }\end{array}$ & $\begin{array}{l}\text { (1) Medical impacts: } \\
\text { (negative physical } \\
\text { effects of skin cancer } \\
\text { treatment, death, } \\
\text { disfigurement); (2) } \\
\text { Non-medical impacts } \\
\text { (social impact, } \\
\text { financial impact, } \\
\text { emotional pain); (3) } \\
\text { Discoloration; (4) } \\
\text { Other. }\end{array}$ & $\begin{array}{l}\text { "Cancers of the lip, } \\
\text { however, are usually } \\
\text { the squamous cell } \\
\text { type, and if untreated } \\
\text { or neglected can } \\
\text { displace bad cells to } \\
\text { the neck nodes, lungs, } \\
\text { liver and other } \\
\text { organs" ("Seal Your } \\
\text { Lips," 1997). }\end{array}$ \\
\hline
\end{tabular}




\begin{tabular}{|c|c|c|c|}
\hline Benefits & $\begin{array}{l}\text { Information about } \\
\text { beneficial } \\
\text { outcomes of } \\
\text { adopting healthy } \\
\text { skin practices. }\end{array}$ & $\begin{array}{l}\text { (1) Avoidance of } \\
\text { negative effects } \\
\text { (avoiding skin cancer, } \\
\text { treatments and } \\
\text { surgery; avoiding pain } \\
\text { (physical and } \\
\text { emotional); avoiding } \\
\text { disfigurement and } \\
\text { scarring; (2) Pre- } \\
\text { venting death; and (3) } \\
\text { Other, such as } \\
\text { avoidance of fear and } \\
\text { the unknown; and } \\
\text { improved quality of } \\
\text { life. }\end{array}$ & $\begin{array}{l}\text { "Proven benefit in } \\
\text { reducing the risk of } \\
\text { cortical cataracts" } \\
\text { ("Sunglasses," } \\
\text { 1999). }\end{array}$ \\
\hline Barriers & $\begin{array}{l}\text { Content in } \\
\text { articles or } \\
\text { illustrations that } \\
\text { mocks, teases, } \\
\text { exploits, or re- } \\
\text { affirms fears and } \\
\text { reasons against } \\
\text { self-care. Nega- } \\
\text { tive language. } \\
\text { Acknowledging } \\
\text { or affirming rea- } \\
\text { sons why golfers } \\
\text { avoid good skin } \\
\text { practices. Sup- } \\
\text { porting reasons } \\
\text { golfers may avoid } \\
\text { self-detection \& } \\
\text { medical expert } \\
\text { detection \& inter- } \\
\text { vention; ambig- } \\
\text { uous information }\end{array}$ & $\begin{array}{l}\text { (1) Social influences } \\
\text { (vanity, social } \\
\text { stigma); (2) Physical } \\
\text { barriers (interferes } \\
\text { with play of game, } \\
\text { inconvenience); (3) } \\
\text { Ignorance, forgetting, } \\
\text { unmotivated; (4) Fear } \\
\text { (anxiety; fear of } \\
\text { truth); and (5) Other } \\
\text { (ambiguity, cost) }\end{array}$ & $\begin{array}{l}\text { "Your wife made you } \\
\text { wear it - } 110 \text { SPF } \\
\text { sunscreen too" (The } \\
\text { subhead reads: } \\
\text { "Here's what your } \\
\text { headwear says about } \\
\text { you"). Photo of a } \\
\text { straw panama hat in a } \\
\text { rating grid of } 17 \text { hats. } \\
\text { The hat was in the } \\
\text { Boomer/Functional } \\
\text { quadrant and not as } \\
\text { attractive as some of } \\
\text { the other hats ("Head } \\
\text { Cases," 2018). }\end{array}$ \\
\hline $\begin{array}{l}\text { Promotion of } \\
\text { self- } \\
\text { efficacious } \\
\text { behaviors }\end{array}$ & $\begin{array}{l}\text { Content that may } \\
\text { increase } \\
\text { confidence in } \\
\text { taking positive } \\
\text { action to protect } \\
\text { skin and prevent } \\
\text { skin cancer. } \\
\text { Includes specific }\end{array}$ & $\begin{array}{l}\text { (1) Adoption of } \\
\text { prevention and early } \\
\text { detection behaviors } \\
\text { (solar UV protection } \\
\text { tips excluding } \\
\text { sunblock; using } \\
\text { sunblock; tips on UV } \\
\text { avoidance; avoiding }\end{array}$ & $\begin{array}{l}\text { "Knowing how to } \\
\text { check for non- } \\
\text { melanoma (basal cell } \\
\text { and squamous cell) } \\
\text { and melanoma, the } \\
\text { deadliest form of skin } \\
\text { cancer can save your } \\
\text { life" ("Beating Skin }\end{array}$ \\
\hline
\end{tabular}




$\begin{array}{ll}\begin{array}{ll}\text { information that } \\ \text { guides or }\end{array} & \begin{array}{l}\text { tans and burns, and } \\ \text { general mentions); (2) }\end{array} \\ \text { instructs } & \text { Medical (making } \\ \text { behavior. } & \text { appointments with } \\ & \text { medical professionals, } \\ & \text { advances in medi- } \\ & \text { cine); (3) ABCDE } \\ & \text { mole test and skin } \\ & \text { self-exams, (4) other }\end{array}$

Intercoder reliability. To establish intercoder reliability, the coding scheme was first tested with a communication studies graduate student and revisions were made based on the discussions. A second coder was trained, and she and the author both coded $15 \%$ of the sampled articles that were randomly selected. The Cohen's Kappa scores for the five variables were: susceptibility $(0.70)$; severity $(0.53)$; benefits $(0.81)$; barriers $(0.73)$; and promotion of self-efficacious behaviors (0.58). Cohen's guidance on Kappa results were: "values $\leq 0$ as indicating no agreement and $0.01-0.20$ as none to slight, $0.21-0.40$ as fair, $0.41-0.60$ as moderate, $0.61-0.80$ as substantial, and $0.81-1.00$ as almost perfect agreement" (Landis \& Koch, 1977). Bakeman and Quera (2011) opined that exceptions exist due to other factors. Examples they cite are bias and accuracy of the observers; prevalence of some codes and the number of codes; and observer independence. A lower Kappa value can be accepted when there are fewer than five codes (Chen, 2019) and therefore the lower Kappa scores of the current study (i.e., 0.53 for severity and 0.58 for self-efficacious behaviors) were acceptable.

\section{One-on-One Interviews}

Participants. Twelve men, aged 21 to 87 , who all played golf at least six times per year, were interviewed for the research. Nine subjects in the study played golf at least 
one time per week during the golfing season. Letters asking the men to participate in the research were sent by email to 21 individuals. The 12 respondents were identified by number in the compilation and analysis of their responses. Because the novel coronavirus COVID-19 had caused a nationwide closure of the economy during the creation and approval of the research study, accommodations for interviewing the individuals was a necessity. In lieu of in-person focus group sessions, which would have violated both Governor Gina Raimondo's Stay-At-Home Executive Order and later, the gathering of small groups, the University of Rhode Island Institutional Review Board approved interview questions and conducting interviews via Google Meet. Of the 12, only two of the subjects were not able to establish the necessary G-mail accounts to access the Meet app and were interviewed by telephone. Notes from their interviews were used in the analysis. Eleven of the men resided in Rhode Island and one was a long-time resident of Massachusetts who changed residency to Rhode Island during the pandemic. Two of the 12 were residing in rental or second homes in Florida and New York during the pandemic.

Interview Procedure. All but two interviews were conducted via Google Meet, an audio and visual platform. These were recorded and transcribed. Two were conducted via telephone, and notes were created. All respondents were asked the same questions, and they were allowed to offer commentary related to the topic of ultraviolet solar radiation, the measures they employ to protect their skin, and the influence that golf magazines have had on their beliefs and practices related to ultraviolet risk-reducing skin care. The average interview length was 30-40 minutes. 
Interview Questions. The men were asked if they recalled reading articles with advice on how to protect themselves from ultraviolet solar radiation in Golf Digest, Golf Magazine and/or Golf World. They were also asked an open-ended question about their recall of articles and photos in these golf magazines about sun protection, sunburn/golf tan avoidance, skin cancer, sunscreen, and similar. These two questions were relevant to RQ3 and if the golf periodicals were memorable for their sun safety messaging.

Some of the prepared questions were written to gather information about their perceptions of their skin cancer risks (perceived susceptibility); their understanding about the seriousness of the disease and its treatment (perceived severity); their positive impressions about self-care and skin protective practice (beneficial actions); why they do or do not engage in some or all of the skincare recommendations of experts (barriers to action); and whether they can be or have been influenced by golf magazine content to adopt all ultraviolet protective measures (self-protection measures).

For example, the men were asked if they believed they were at risk to develop skin cancer. To probe further, they were asked an open-ended question about why they thought they were susceptible or not susceptible. The two-part question helped shed light on their motivations for their skincare measures. They were asked about how they learned to protect their skin from the sun and who were the most influential sources of that information. To determine if the first-hand testimonials of professional golfers treated for skin cancer could be a factor for improved skincare routines, the golfers were asked about their knowledge of golf professionals with skin cancer and how reading about their treatments would influence them. The men were also asked to list their sun-safe practices 
while golfing to compare their behavior with research findings as well as what had been advised via the editorial content of the golf magazines.

Table 3 Examples of interview questions

Do you recall having read in any golf magazine about an increased risk of skin cancer among men who play golf regularly? Do you believe you are at risk? Why or why not?

Of the items you mentioned earlier that you do to protect your skin, why are you doing this?

Of the things you do to protect your skin, why are you doing this?

Would you find it helpful or not helpful to read information frequently about skin cancer health-related news in golf magazines? Why?

Please identify measures that you, as a golfer, practice on the golf course to protect skin from ultraviolet solar radiation. 


\section{CHAPTER 4}

\section{RESULTS}

\section{Content analysis results}

Text and imagery of 64 articles were examined, and only four articles in the magazines examined were comprehensive enough to cover the scope of the issue, such as long-term and persistent threats to the golfing population, how to identify suspicious moles, and the best methods to protect skin. The repetition of topic was not evident because the total number of articles over 20 years numbered 72 .

The most common health belief model construct within the 64 articles and 69 images was content that promoted self-efficacious actions $(n=55)$; followed by benefits $(n=36)$; susceptibility $(n=33)$; barriers $(n=30)$; and severity $(n=29)$ (See Table 4 for a detailed description of each construct's coding results).

Table 4 Health belief model construct frequencies

\begin{tabular}{|l|c|}
\hline Construct & $\begin{array}{c}\text { \# of Articles/Images } \\
\text { Coded }\end{array}$ \\
\hline (N/64) \\
\hline Susceptibility & 33 \\
\hline Lifetime UV exposure effects, cumulative effects & 15 \\
\hline Skin cancer statistics: & 14 \\
\hline Prevalence of skin cancer rates among men & 7 \\
\hline Mortality rates, death rate & 7 \\
\hline Mention about incidence among pro golfers & 12 \\
\hline Other & 21 \\
\hline Severity & 29 \\
\hline Medical impacts: & 29 \\
\hline Negative physical effects of skin cancer treatment & 11 \\
\hline Death & 11 \\
\hline Disfigurement & 7 \\
\hline
\end{tabular}




\begin{tabular}{|c|c|}
\hline Discoloration & 16 \\
\hline Non-medical impacts & 9 \\
\hline Social impact & 5 \\
\hline Financial impacts & 3 \\
\hline Emotional pain & 1 \\
\hline Other & 14 \\
\hline Benefits & 36 \\
\hline Avoidance of negative effects & 22 \\
\hline Avoiding skin cancer, treatments and surgery & 16 \\
\hline Avoiding pain (physical and emotional) & 5 \\
\hline Avoiding disfigurement and scarring & 1 \\
\hline Preventing death & 9 \\
\hline Other & 19 \\
\hline Avoidance of fear and the unknown & 1 \\
\hline Improved quality of life & 1 \\
\hline Barriers & 30 \\
\hline Social influences & 15 \\
\hline Vanity reasons & 8 \\
\hline Social stigma & 7 \\
\hline Physical barriers & 13 \\
\hline Interferes with play of game & 11 \\
\hline Inconvenience & 2 \\
\hline Ignorance, forgetting, unmotivated & 13 \\
\hline Fear & 2 \\
\hline Other & 11 \\
\hline Ambiguity & 4 \\
\hline Cost & 0 \\
\hline Promotion of Self-Efficacious Behaviors & 55 \\
\hline Adoption of prevention and early detection behaviors & 76 \\
\hline Solar UV protection tips excluding sunblock & 33 \\
\hline Using sunblock & 26 \\
\hline Tips on UV avoidance (seek shade, off tee times) & 8 \\
\hline General mention & 6 \\
\hline Avoiding tans and burns & 3 \\
\hline Medical & 17 \\
\hline Making appointment with a medical professional & 12 \\
\hline Advances in medicine & 5 \\
\hline ABCDE mole test, skin self-exams & 9 \\
\hline Other & 13 \\
\hline
\end{tabular}


Susceptibility. Just over half of the articles reviewed ( $n=33)$ published content related to susceptibility. Mention of the long-term and cumulative effects of UV solar radiation garnered the most coverage $(n=15)$, followed by statistics about how the disease affects the population or golfers more specifically $(n=14)$. Lengthy articles were more likely to convey information about the mortality rate among golfers $(n=7)$ than shorter articles, for which susceptibility messaging was more likely to be broad ("1 in 5 Americans will get skin cancer") (Barton, J. (2010); not correlated to golfing ("incidence of skin cancer among Americans rose 50\% between 1980-1990") (Horton, 1997); or highly specific to a body part rather than overall risk ("lower lip is especially susceptible to skin cancer") (Kapriske, 2010). It was more common for the magazines to publish broad statements rather than scientifically-based statistics, such as, "Golfers face an elevated risk of developing all sorts of skin trouble" ("Dodging the Big C," 2002). When statistics were published, they tended to be about the broader population in the United States than that of golfers ("Skin cancer will affect about 1 million Americans this year (Malanka, 1996), and the susceptibility of an ill-defined set of people rather than golfers specifically. Eleven articles featured the perspective of professional golfers who had undergone skin cancer treatments, inferring that cumulative exposure and multiple sunburns like they had experienced translates to an elevated risk for the disease for other golfers.

Despite warnings that younger golfers are most at risk for melanoma (American Academy of Dermatology, 2019), none of the magazines published photos depicting sunburned individuals or youthful-looking players. Images that accompanied articles about susceptibility typically featured burned objects, such as a golf ball (Day et al., 
2015), or a marshmallow (Kaspriske, 2008), or eyeballs (Patterson, 2007). The most frequent images were products, such as clothing and sunblock bottles.

Severity. Overexposure to UV solar radiation can result in two types of impacts: medical and non-medical. Content explaining some of the medical impacts included examples of the negative physical effects of skin cancer treatment $(n=11)$; death from melanoma, the most severe form of skin cancer $(n=11)$; and disfigurement $(n=7)$, especially to the face and head. One striking example of images used to portray the severity of ultraviolet solar radiation damage was a quartet of color headshots of professional senior tour golfers paired with their black-and-white ultraviolet photo headshots, which revealed sun damage to the head not visible to the eye. Captions accompanied the images and noted the professional golfers' comments about the ultraviolet photos and their opinions about sunburns, skin cancer, and their own susceptibilities. Discoloration of the skin, which included both burning and tanning, especially the so-called "golf tan," was a frequent topic $(n=16)$. Interestingly, none of the 64 articles over the 20-year period featured an image of a sunburned or overly tanned golfer despite the fact that the severity of repeated, frequent or sustained discoloration of skin is a prime factor for skin cancer. Although mentioned frequently in the text, sunburning, as a severity construct, was not represented well with imagery. Despite the severity that non-medical consequences can have upon a life, it was not a topic well covered in golf magazines. Examples of these effects included social $(n=5)$ ones, such as not playing golf while undergoing treatment; financial $(n=3)$, which could be devastating for the uninsured; and emotional $(n=1)$, such as depression and anxiety. Only one article mentioned the emotional pain related to an oncologist visit, regret, or one's mortality. 
Nevertheless, warnings were present about the irreversibility of eye damage due to ultraviolet exposure; risks of reoccurrences of lesions and moles needing treatments; and disfigurement due to surgery.

Benefits. This construct was prevalent in the golf publications, perhaps due to the frequency of publicity about sunblock and its association as a preventative measure against skin cancer. Of the articles and images evaluated, most in this construct promoted avoiding the overall negative effects of skin cancer $(n=22)$, especially its treatments, such as burning off lesions and spots or surgical removal of large patches of skin $(n=16)$; avoiding both physical and emotional pain $(n=5)$; and resulting disfigurement and scars of treatment $(n=1)$. Preventing death messaging $(n=9)$ was included in content that positioned melanoma as the worst type of skin cancer in comparison with basal cell and squamous cell carcinoma. Sometimes, the brevity of the text — such as "block those rays" ("The Skinny On Sunscreens," 1998) — required readers to understand the correlation of using skin products with SPF with preventing skin cancer but without explicitly stating so.

Barriers. Social influences, i.e., the appearance one presents to the public and the force of peer pressure upon the self, were present in the magazines, usually as humor $(n=15)$. Vanity reasons were cited in eight of the articles. Ridiculing wide-brimmed hats as unfashionable because " your wife made you wear it" ("Head Cases," 2018) and wraparound sunglasses that protect eyes from ultraviolet radiation as "looking like an extra from a low-budget sci-fi B movie" (Barton, 1995) reinforced a common barrier for golfers considering or employing these recommended protections. In a first-person narrative, a writer (Owen, 2019) stated that many golfers came of age in an era where 
darkening one's skin was widely practiced and a norm. Other content revealed attitudes about skin cancer held by golfers when discussing their cases.

Padraig Harrington had a 'sun spot' removed from his forehead last week according to the Irish Independent newspaper. The spot, a patch of "nonmelanoma skin cancer" was nothing serious, according to Harrington. "It was continuing to expand, so it was decided to catch it before it got any bigger," he told the paper. "It's nothing exciting. Just standard procedure." (Antonini, 2007)

Masculine norms about toughness when facing with adversity could be a factor in the aforementioned story (Geller et al., 2006; Office of the Surgeon General, 2014) and the attempt by the golfer to downplay the impact of skin cancer as a sun spot, the removal of which was de rigueur.

Products perceived to interfere with the play of game were also coded as barriers. The most common examples were sunglasses, which are believed to make it more difficult to read the greens or see golf balls, and sunblock that leaches into the eyes or is messy to apply. The inconvenience of applying and reapplying sunblock was an obstacle acknowledged $(n=2)$.

Confusion about the efficacy of sunblocks, SPF ratings, and ignorance about the signs of skin cancer, when to see medical professionals, and the susceptibility of skin on lips and eyes were factors in seven of the articles.

Promotion of self-efficacious behavior. Information that educates readers about actions they can adopt to prevent skin cancer is critical to helping them detect cancers early, avoid or block ultraviolet solar radiation, and empower them to seek help from medical professionals. This is especially powerful advice because preventive actions and early detection of suspicious moles and spots can help stop onset of disease or mitigate its 
advance $(\mathrm{n}=76)$. Seeking shade, choosing tee times early or late in the day, covering arms and legs, and wearing hats was the popular advice ( $n=33)$, even when excluding sunblock. Repeated promotion of sunblock usage $(n=26)$ can aid behavioral adoption, but the prevalence $(n=15)$ of the branded bottles of sunblock does not further understanding about the best methods to apply and use the product. One exception was an article that featured a photograph of professional golfer Ernie Els with a white layer of sunblock on the back of his neck, and applying more to his cheek. The sub-headline, "Sunscreen isn't enough. Keep an eye on those moles" led readers into self-help text about booking appointments with dermatologists and checking moles monthly (DiMenna, 2005). Seventeen articles either stressed the importance of making appointments with physicians or spotlighted advances in how skin cancer is treated, which has made it one of the most treatable of all cancers. In total, nine articles featured skin tests. Three included color photographs of irregular moles $(n=1)$ and the ABCDE self-test for melanoma detection $(n=2)$.

Overall, only $15 \%$ of the articles made note of the fact that male golfers have a higher risk of skin cancer, and just seven mentioned that skin cancer, particularly melanoma, is deadly. Ninety-one percent of the content presented information about prevention with either the benefits and/or promotion of self-efficacious behaviors. Eight articles presented in-depth commentary about golfer risks for skin cancer based the ultraviolet levels of solar radiation exposure, solutions to exposure, and deeper context of the threats. Over a quarter of the content analyzed $(n=18)$ featured an image of a sunblock bottle or a pair of sunglasses with bland headlines such as "shades of protection" or "sun protection." 
Generally, the texts of the examined magazine articles were more descriptive and informative than their accompanying images for conveying ultraviolet solar radiation and skin cancer protection advice. Over a quarter of the content analyzed $(n=18)$ were images of products - sunblock bottles, sunglasses, clothing, and a watch — rather than action photos of individuals applying sunblock, wearing sunglasses while playing golf, or similar. Explanations about why a reader needed sunblock or sunglasses were omitted. Eight articles over the course of the 20 -year period provided in-depth, contextual understanding of the susceptibility male golfers face in developing skin cancer; the severity of the disease to their well-being; the benefits of avoiding cancer, eye diseases, and other physiological negative effects of ultraviolet solar radiation; the barriers, myths and obstacles men face regarding protecting their skin during gameplay; and explanations of behaviors golfers can adopt to protect themselves from solar carcinogens.

\section{Interview Results}

Eleven of the respondents did not recall reading any content in golf magazines, either in paper or online, related to ultraviolet solar radiation protection. The one individual who recalled reading relevant content revealed that he was a cancer survivor and that other family members had been diagnosed with and treated for skin cancer. Importantly, recall about the origins of read content was very difficult to accurately state.

Nine of the 12, when asked how they learned to protect their skin from cancer, stated that they learned from a medical professional. Although the subjects were not asked to reveal the type of medical professional, five responded that they had learned from a dermatologist. Friends and family members as well as print and broadcast media news outlets were mentioned as entities that taught them about skin care. Unique answers 
about where they learned about skin protection included coaches and public education campaigns at work. One sexagenarian golfer stated that he never received any advice nor practiced any ultraviolet solar protection measures because of his ethnicity and that his olive-colored skin does not burn.

How are the golfers protecting their skin? Eleven of the twelve reported that they seek shade, although some admitted that the shade also provided relief from the heat as well as the sun's burning rays. Getting cool rather than reducing ultraviolet solar exposure was the primary intent. Said Golfer \#3,

Staying in the shade, I would just get hot so I would go step into the shade...It's a mix. Sometimes (going to shade is) to cool down. Sometimes it is because I can feel myself getting burned. And usually toward the end of the course I'll try to steer closer to the shade to avoid getting more burned.

Choosing early morning or late afternoon tee times, when the ultraviolet solar rays are less intense, was not a consideration for any of the golfers interviewed. They universally agreed that they preferred tee times based on their own schedules or accepted the time slots available by the course. Many golf in late-afternoon leagues, therefore they are not deliberately avoiding the sun.

Ten of the 12 golfers said they use sunblock, which was the most popular form of skin protection touted by the golf magazines studied. The men who replied that they do not use sunblock revealed that they have dark skin due to continuous ultraviolet radiation exposure and naturally darker shades of skin. Ten revealed that they believed to be at-risk for skin cancer, and two mentioned that they had been treated for melanoma and precancerous lesions. The reasons the male golfers offered about their beliefs about their own risks for skin cancer included the paleness of the skin, lack of motivation to apply sunscreen, family history, prior sunburns, and outdoor work. 
None of the golfers interviewed wear long pants, and two wear long sleeves only periodically and during cooler, spring weather. Rather than cover exposed arm and leg skin, they cited comfort as the prevailing reason for the clothing choices. One mentioned that he works indoors all day and usually plays only in the season. Wearing casual clothes to play his sport, he said, is more comfortable than his formal work clothes.

To protect the top of the head, ears, face and the back of the neck from solar radiation, a hat is recommended by experts. Most of the respondents wear one while golfing, but only four of the 12 said they choose hats with a wide enough brim to protect the back of the neck. Admitted Golfer \#5, "I tried wearing a brimmed hat and hated being the only one wearing the hat" and stopped wearing it. Of the hat-wearing golfers interviewed, most (5/8) choose baseball-style hats.

When queried if they would be likely to adopt some or all of the recommended measures for maximum ultraviolet solar protection (i.e., seeking shade, avoiding sun, covering up, and wearing sunblock) if golf magazines printed articles about skin cancer rates for golfers and professional golfer stories about their own skin cancer health scares, most replied they would (6/12) and would consider it (4/12). Only the men who did not wear sunblock replied that they would not be interested in reading content in golf magazines about protecting their skin.

A common thread of the golfers' replies about covering exposed skin related to fashionable clothing. They were very interested in adopting fashion endorsed by and worn by professional golfers. Said Golfer \#1, 
Phil Mickelson's got this goofy set of glasses he wears now because someone's paying him $\$ 500$ grand to wear them, and now everyone's buying them, right? So if they find out that arm sleeves are protective and pros wear them, people are going to buy them, right?

The professional golfers hold the interest of the interviewees, not only in fashion but in new equipment trends. They remarked that if new golf accoutrements included ultraviolet solar protective clothing or products such as arm sleeves, they expressed their proclivities to explore and adopt the trends. One remarked that he enjoyed reading about products that are advancements in technology and was open to hearing golf professionals' opinions about the products that were new and protective as long as golfing information was not eclipsed by health and beauty news.

Because of the golfers' revelations that they did not recall golf magazine articles about skin cancer, elevated incidences among male golfers, or skin protection advice, it suggests that the content they are reading in the golf magazines isn't powerful enough to trigger recall, or frequent enough that they know that the content is published even if they can't remember the specifics on the content. Nevertheless, none cited golf media specifically as a channel for educating themselves on ultraviolet radiation protection. It is therefore reasonable to conclude for RQ3 that the male golfers are not following advice about skin cancer protection measures that are published in golf magazines. 


\section{CHAPTER 5}

\section{DISCUSSION}

The first research question asks to what extent skin cancer protection is covered by golfing magazines? For a sport with a higher than average rate of skin cancer among its participants (Matthews et al., 2018), the dearth of content related to protecting their health while playing the sport is noteworthy. Over the course of 20 years, three golfspecific magazines published 72 articles related to skin cancer and ultraviolet solar radiation protection advice. Some content was nothing more than an endorsement of a brand of sunblock and a caption about its favorable attributes (e.g., scent, sweat-proof). Often, the text presumed that the reader understood that sunblock lotions, sunglasses, brimmed hats and seeking shade protect against skin cancer without explicitly stating that fact. While some articles touted sunblock, sunglasses and skin exams as essential preventative measures, they lacked explanations about why they are essential. Repeated, small exposures to radiation results can and often does lead to cancer, but discussion of ultraviolet radiation is not framed as carcinogenic. Reframing the danger of sun exposure as exposure to a carcinogen could change golfer perceptions. Helping golfers understand the medical and non-medical implications related to their overall risks by repetition of facts can lead to greater awareness of the severity of the disease. The opportunity to educate or reinforce information about skin cancer diagnosis rates among male golfers could be much improved.

The second research question asks to what extent golf magazines give advice about the severity of skin cancer and men's susceptibility to it as well as acknowledging 
the barriers and benefits of avoidant and protective tactics. Only eight articles were complex, multi-page discussions about skin cancer, its prevalence rates among golfers, how to avoid cumulative exposure, who to consult, and how to conduct self-exams. Although the interviewees who read golf publications said they read them to improve their skills rather than for health advice, an amplification of warnings coupled with recommendations could help persuade men with a casual interest about their player risks to feel more empowered about the content they have read and increase their selfprotective behaviors. Directly addressing social and physical perceptions of barriers including lack of knowledge directly instead of couching it in sarcastic humor can improve player safety.

As noted by McWhirter \& Hoffman-Goetz (2016) weaknesses of model constructs in the imagery hinders messaging. Interestingly, none of the 69 images in the published articles depicted sunburned men or young men. Sunburns and the ill-defined term "sun damage" were discussed frequently, but the accompanying imagery tended to be illustrations of men, the sun, or products. One photograph published together with a message about sun protection was of a blonde professional golfer in a cheesecake pose wearing a mini-dress with her bare shoulders and arms exposed. If the images of golfers are limited to older men, younger men may not connect that they are a susceptible group. Cartoons of men in exaggerated brimmed hats, illustrations of golfer faces as roasted marshmallows, and golfers photographed from behind may hinder the questioning of susceptibility by those most at risk.

Some of the most impactful photos published were the mugshot-style ultraviolet photographs of four professional golfers, ages 53-58, next to their color photos. Sun 
damage to their heads was evident, and their first-person accounts of painful sunburns, surgical procedures, and impressions about their damaged pigmentation was compelling. The golfers interviewed said they enjoyed reading about professional golfers, and this article stood out from the rest for inclusion of candid remarks and impressions. The 5,696-word article was peppered with first-hand accounts of PGA players, the impacts of too much sun exposure, skin cancer prevention and treatments, and advice from dermatologists. It also featured photos of an assortment of moles and cancer lesions to help readers learn how to identify their own skin concerns.

Golf professionals, according to the men interviewed, are seen as authorities and their opinions about golf are influential. If the pros were to speak more openly and candidly about their own skin cancer treatments, the effect on amateur sportsmen would help raise awareness of the frequency of diagnosis, the severity of the disease, and the ability to engage in self-protection to avoid similar consequences. One interviewee said he hoped that professionals would endorse items such as wide-brimmed hats so that the hats would become fashionable and sought-after, rather than ridiculed.

Similar to research findings that recognized sunblock popularity (Anderson et al., 2017; Bleakley et al., 2018; Dixon et al., 2008), sunblock was the most frequent ultraviolet protection method noted by the golf magazines. The majority of study interviewees (10/12) also reported their favoritism toward sunblock usage. However, promotion of all UV solar protection methods used in combination (seeking shade, sunblock, avoiding sun at midday, wearing a wide-brimmed hat), as recommended by dermatologists, was rare in the articles or by the interviewees (Bleakley et al., 2018). As noted by Cokkinides et al. (2012), details about how to use sunblock successfully are 
neglected. A photograph of Ernie Els with a heavily whitened neck applying sunblock to his face was the only image of 69 depicting application. A respected professional golfer modeling good behavior was relatable, and the text reinforced messaging about conducting self-exams, consulting dermatologists, the benefits of early detection, and the consequences of cumulative exposure. For a short article ( 339 words plus 1 photo), its comprehensiveness stood out from the rest.

Some content conflated sun protection with other benefits not related to ultraviolet solar protection. For example, wearing hats and sunglasses were promoted as stylish sun protection purchases rather than skin cancer protection. Product attributes, especially in 2019, focused on their environmentally friendly sourcing and safety to reefs (Vaughn, 2019; Mayo, 2019) rather than user protection against skin cancer. One article highlighted that the sunblock was formulated to protect the face without mention that the face, ears, nose and lips are the most common sites for skin cancer (Mayo, 2019). It can be inferred that the formulation was non-comedogenic rather than extra potent.

The third research question asked whether male golfers are following advice about skin cancer protection measures published in golf magazines. The interviewed golfers seemed aware of their own risks, citing light skin tone, family histories, and lack of sunburn protection, yet nearly all revealed that do not adhere to good skin protection routines every time they golf. The disconnect about their awareness of their cancer risks and undisciplined approach to protection was consistent with prior research (Barrett, Usher, Woods, \& Conway, 2019; Bleakley et al., 2018; Parsons et al., 2018). Generally, their self-admitted suboptimal performance springs from a lack of awareness about risk, 
unenthusiastic attitude for consistent ultraviolet radiation protection during golf, and uncomfortableness of appearing different than other golfers.

The extent of the impact of the 64 articles evaluated is unknown but among those interviewed in this research, the editorial content had little impact. The men did not recall reading content in these three magazines about the risks of sunburning and overexposure to ultraviolent radiation, therefore messaging about their skin cancer risks did not have enough impact to influence behavior.

\section{Limitations}

The content analysis retrieving all the content dating back 20 years had limitations due to copyright issues. More content is published in other mediums, especially golfing websites, whereby the content could be more engaging, interactive, and informative. The coder's assessment of the articles may not be in agreement with other's perceptions of the content. It is unknown if gear such as sunglasses, sunblock and hats are the result of product placement and authored by manufacturers with an intent to sell rather than to educate.

Future researchers could examine the download and/or click rates of online magazine content about skin cancer protections and the incorporation of health benefit model constructs. A large-scale reader survey of subscribers about the topic would target the audience more precisely and could serve as a helpful tool for parties crafting educational messaging about skin cancer avoidance. Future researchers can also evaluate the effectiveness of advertising messages that promote skin cancer products, alone or with editorial content, on male golfers. This information can help determine if a multidisciplinary approach in the golf magazines can be effective in persuasion. 
The interview research focused on three vertical publications from which recall about content would be difficult to discern. Some of those interviewed were too young to recall content dating back 20 years; some were infrequent readers; and some haven't read golf magazines at all. The small number of interview subjects, not representative of the American male golfer, cannot be projected to a larger number of male golfers. Drawing a conclusion about the impact the publications have had on behavior is a limitation of the scope.

Because the study lacks information about how much content was read in the golf magazines by the men interviewed in the study, future researchers can do an experimental study in which a sample of male golfers are provided editorial (and/or advertising) content with skin cancer information (e.g., their unique susceptibility to skin cancer, the disease's severity, purported barriers among male golfers, information about the beneficial outcomes of adopting healthy skin practices, and actions promoted to help them prevent skin cancer as well as identify signs of disease). Contrasting this group of male golfers with another group of male golfers who have not been exposed to that messaging through a follow-up survey to see if they have changed any of their sun protective behaviors about golfing can illuminate the effectiveness of the channel. 


\section{Conclusion}

Opportunities exist for golf magazines to engage more frequently with readers about the skin cancer realities of the sport. Content that addresses susceptibility factors, such as statistics about skin cancer diagnoses among male golfers; melanoma fatality statistics; and the growing risk to males under age 35 is warranted. The severity of the physical and emotional pain associated with a cancer diagnosis has not been fully or frequently conveyed to readers. For future content to be effective, it will need to confront barriers, such as masculinity norms and the lack of regimented protection routines, and encourage men to adopt the behaviors that will be most efficacious for their health. Writers and editors should not shy away from using the term "skin cancer" or "melanoma" when promoting the benefits of products such as sunblock, sunglasses, and wide-brimmed hats. Advertising by manufacturers of these products should take notice of the opportunities for increased awareness and concentration of the cancer-protective attributes of their merchandise. For designers of public education campaigns, adding the perspective of golf professionals who have experienced skin cancer with increased frequency to articles will help get traction with this high-risk audience who respect PGA celebrity players. The Office of the Surgeon General (2014) specifically recommended targeted media messages for male golfers about their unique cancer risks and how and when to use sun protection. The explicit mention of cancer as a player risk, demonstrations about how to apply sunblock, and why the ultraviolet protective measures used in tandem will offer the most protection is essential. 


\section{APPENDIX A}

\section{Magazine articles included in the content analysis}

1. All the right moves. (2005). Golf World, 59(19), 6.

2. Aloe, I love you. Save strokes with this first-rate sunblock. (2007). Golf, 49(6), 35.

3. Antonini, J. (2011). Front 9. Golf World, 64(23), 19.

4. Antonini, J. (2007). The Fringe. Golf World, 60(35), 55.

5. Avery, B. (2011). North Remains Example For All Regarding Skin-Cancer Screening. Golf World 64(18).

6. Barton, J. (1995). In the eye of the beholder. Golf Digest, 46(9), 154.

7. Barton, J. (2010). The top 60 innovations of golf's modern era. Golf Digest, 61(9), 118.

8. Broderick, E.R. (1994). Various shades of protection. Golf Digest, 45(7), 90.

9. DiMenna, B. (2005). Skin protection. Golf Digest, 56(6), 104.

10. Dodd, A., \& Kaspriske, R. (2009). Enough With The Rough. Golf Digest, 60(10), 12.

11. Dodging the Big C. (2002). Golf Digest, 53(9), 74.

12. Don't let the sun go down on you. (2001). Golf Digest, 52(11), 30.

13. Farnsworth, C., \& Smith, S. (1999). Sunglasses. Golf Digest, 50(8), 113.

14. Gravel, T. (1997). Shady outlook. Golf Magazine, 39(5), 136.

15. Gravel, T. (1997). Skin cancer. Golf Magazine, 39(7), 116.

16. Haney, H. (2008). You Want a Piece of Me? Golf Digest, 59(7), 139. 
17. Head Cases. (2018). Golf Magazine, 60(2), 82.

18. Here Comes the Sun. (2003). Golf World, 56(43).

19. Herrington, R. (2009). The Front 9. Golf World, 62(29), 23.

20. Hochswender, W., Walker, M., Marksbury, J., \& Beslow, S. (2010). Shades of the Future. Golf Magazine, 52(5), 24.

21. Horton, C. (1997). Seal your lips. Golf Digest, 48(9), 139.

22. Hot Head sunscreen. (1995). Golf World, 48(39), 5.

23. Hot line. (1998). Golf Magazine, 40(7), 134.

24. Kaminer, M. (2006). Beating Skin Cancer. Golf Digest, 57(8), 127.

25. Kaspriske, R. (2005). The Essentials. Golf Digest, 56(11), 154.

26. Kaspriske, R. (2008). Burned to a Crisp. Golf Digest, 59(7), 136.

27. Kaspriske, R. (2010). Gear: This Block Means No More Tears. Golf Digest, 61(9), 16.

28. Kaspriske, R. (2010). Give Your Lips Some Love. Golf Digest, 61(3), 17.

29. Kaspriske, R. (2012). Suits of Armor. Golf Digest, 63(8), 15.

30. Kaspriske, R. (2017). Burn Notice. Golf Digest, 68(8), 50.

31. Lights Out. (2015). Golf Digest, 66(7), 41.

32. Malanka, P.A. (1996). Sunblock update. Golf Digest, 47(7), 9.

33. Marketplace. (1994). Golf Magazine, 36(7), 100.

34. Marketplace. (1995). Golf Magazine, 37(10), 83. 
35. Marksbury, J., Stricklin, A., Scott, A., Spieth, J., Haas, B., Snedeker, B., Bender, M., Day, J., DeLaet, G., Johnson, Z., Streelman, K., McCabe, B., \& Reed, P. (2015). Look Like a Pro. Golf Magazine, 57(2), 66-70.

36. Mayo, A. (2019). The Things I Carry. Golf Magazine, 61(5), 76.

37. Melanoma: Know the enemy. (2000). Golf Digest, 51(8), 34.

38. Mohler, B. (2014). Miscellany: Harrington Undergoes Skin Cancer Treatment. Golf World. 67(20), 12

39. Murphy, M. (2002). Mike Argyelan. Golf World, 56(5), 16.

40. Owen, D. (2019). We're in Trouble: Skin Cancer Is on the Rise, and Not Just for Golfers. Here's What You Need to Know from a Guy Who Made the Same Mistakes You Have. Golf Digest, 70(7), 66.

41. Patterson, J. (2007). Easy on the Eyes. Golf Digest, 58(9), 66.

42. Protect that bald spot. (2006). Golf Digest, 57(6), 80.

43. Protect your eyes. (2006). Golf Digest, 57(6), 80.

44. Purkey, M. (1995). Heat. Golf Magazine, 37(8), 68.

45. Repel the sun, bugs. (2006). Golf Digest, 57(4), 82.

46. Rudy, M. (2019). These UV photos show the sun's dramatic effect on a handful of senior tour pros. Golf Digest, 57(4), 82.

47. Rushkin, S. The Bald Truth. (2015). Golf Digest, 66(7), 45.

48. Safe Sun. (2011). Golf Digest, 62(8), 48. 
49. Shining New Light On Sun Damage. (2010). Golf Digest, 61(6), 60.

50. Skin to win. (2006). Golf Digest, 57(8), 70.

51. Solar Eclipse. (2010). Golf Digest, 61(7), 36.

52. Soltau, M., \& Stachura, M. (2009). What's In My Bag? Golf Digest, 60(3), 65.

53. Spiranac, P. (2019). There's Room For Everyone. Golf Magazine, 61(4), 25.

54. Stachura, M. (1994). Skin cancer alert. Golf Digest, 45(4), 14.

55. Stachura, M. (1995). Hot topic. Golf Digest, 46(8), 14.

56. Sun protection. (2000). Golf Digest, 51(8), 34.

57. The Most Important Page! (2013). Golf Digest, 64(8), 52.

58. The skinny on sunscreens. (1998). Golf Digest, 49(7), 28.

59. Things every golfer should know. (2007). Golf Digest, 58(3), 68.

60. Thomas, Justin. (2019). What's in my bag. Golf Magazine, 61(11), 48.

61. Vaughn, K. S. (2019). Salt \& Stone Sunscreen Stick. Golf Magazine, 61(10), 108.

62. Warning Signs. The ABCDs. (2000). Golf Digest, 51(8), 34.

63. Watching for sun damage. (2001). Golf Digest, 52(8), 30.

64. What's going on and what's coming up. (1994). Golf Magazine, 36(3), 168. 


\section{APPENDIX B}

Sample images from golf magazines analyzed for skin cancer content in golf magazines.

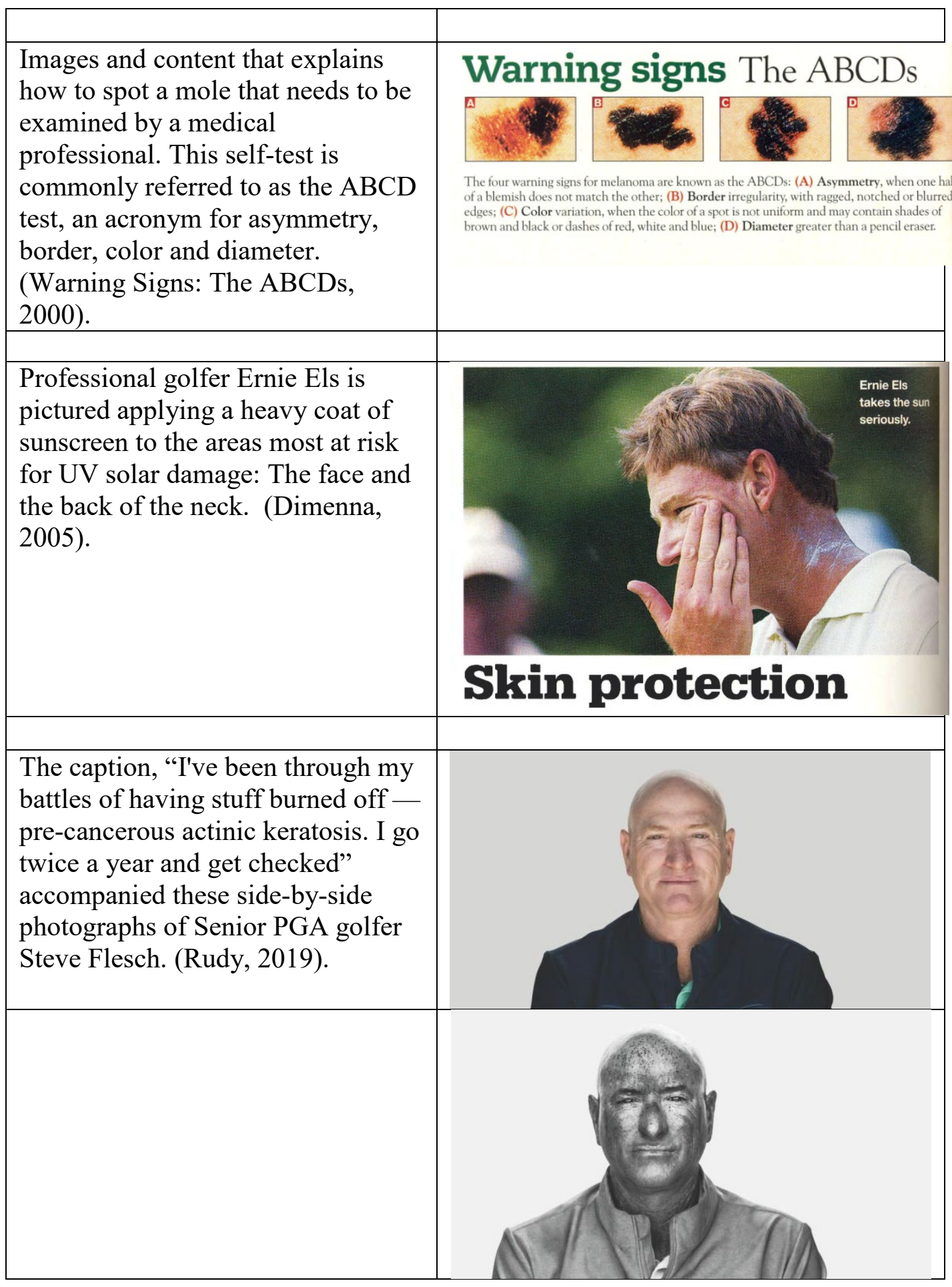




\section{BIBLIOGRAPHY}

American Academy of Dermatology (2019). Skin cancer incidence rates. Retrieved from https://www.aad.org/media/stats-skin-cancer. November 17. 2019.

Andersen, P., Buller, D., Walkosz, B., Scott, M., Beck, L., Liu, X., Abbott, A., Eye, R., Cutter, G. (2017). A randomized trial of an advanced sun safety intervention for vacationers at 41 North American resorts. Journal of Health Communication, 22(12), 951-963. doi:10.1080/10810730.2017.1382615.

Bakeman, R., and Quera, V. (2011). Sequential analysis and observational methods for the behavioral sciences. Cambridge University Press. Retrieved from

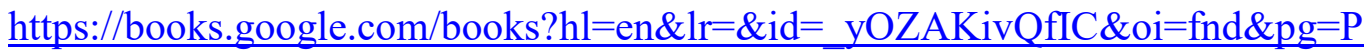
$\underline{\text { R3\&ots }=\text { hZ9XJ--0sd\&sig }=\text { a3nG yVb3S1- }}$

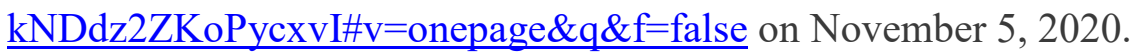

Barrett, F., Usher, K., Woods, C., and Conway, J. (2019). Sun protective behaviours during maximum exposure to ultraviolet radiation when undertaking outdoor activities: An integrated literature review. Journal of Public Health, 27(3), 393405. doi:10.1007/s10389-018-0945-1.

Bleakley, A., Lazovich, D., Jordan, A., and Glanz, K. (2018). Compensation behaviors and skin cancer prevention. American Journal of Preventive Medicine, 55(6). 848-55. doi:10.1016/j.amepre.2018.06.019.

Chen, T.S. (2019) Interpretation of Kappa values: Evaluate the agreement level with condition. Towards Data Science. Retrieved from https://towardsdatascience.com/interpretation-of-kappa-values-2acd1ca7b18f on November 5, 2020. 
Cokkinides, V., Kirkland, D., Andrews, K., Sullivan, K., and Lichtenfeld, J.L. (2012). A profile of skin cancer prevention media coverage in 2009. Journal of the American Academy of Dermatology, 67(4), 570-75. doi:10.1016/j.jaad.2011.11.920.

Dixon, H.G., Lagerlund, M., Spittal, M.J., Hill, D.J., Dobbinson, S.J., and Wakefield, M.A. (2008). Use of sun-protective clothing at outdoor leisure settings from 1992 to 2002: Serial cross-sectional observation survey. Cancer Epidemiology, Biomarkers \& Prevention: A Publication of the American Association for Cancer Research, 17(2), 428-434. doi:10.1158/1055-9965.EPI-07-0369.

Dixon, H., Warne, C., Scully, M., Dobbinson, S., and Wakefield, M. (2014). Agendasetting effects of sun-related news coverage on public attitudes and beliefs about tanning and skin cancer. Health Communication, 29(2), 173-81. doi:10.1080/10410236.2012.732027.

Downs, N., Parisi, A., and Schouten, P. (2011). Basal and squamous cell carcinoma risks for golfers: An assessment of the influence of tee time for latitudes in the northern and southern hemispheres. Journal of Photochemistry \& Photobiology, B: Biology, 105(1), 98-105. 10.1016/j.jphotobiol.2011.07.007.

Downs, N., Schouten, P., Parisi, A., and Turner, J. (2009). Measurements of the upper body ultraviolet exposure to golfers: Non-melanoma skin cancer risk, and the potential benefits of exposure to sunlight. Photodermatology, Photoimmunology \& Photomedicine, 25(6), 317-24. doi:10.1111/j.1600-0781.2009.00472.x.

Geller, J., Swetter, S.M., Leyson, J., Miller, D.R, Brooks, K., and Geller, A.C. (2006). Crafting a melanoma educational campaign to reach middle-aged and older men. 
Journal of Cutaneous Medicine and Surgery, 10(6), 259-68.

doi:10.2310/7750.2006.00066.

Glanz, K., Rimer, B. K., \& Viswanath, K. (2010). Health Behavior: Theory, research, and practice (5th ed). Jossey-Bass, Wiley. p. 78.

Golf Digest media kit. Retrieved from mediamaxnetwork.com on April 15, 2020 citing MRI/ComScore2019.

Gristwood, J. (2011). Applying the health belief model to physical activity engagement among older adults. Illuminare, 9(1), 59-71. https://scholarworks.iu.edu/journals/index.php/illuminare/article/view/1035/1102.

Heneghan, M., Hazan, K., Halpern, C., and Oliveria, A. (2007). Skin cancer coverage in a national newspaper: A teachable moment. Journal of Cancer Education, 22(2), 99-104. doi:10.1007/BF03174356.

Holman, D.M., Berkowitz, A., Guy, G.P., Hawkins, N.A., Saraiya, M., and Watson, M. (2015). Patterns of sunscreen use on the face and other exposed skin among US adults. Journal of the American Academy of Dermatology, 73(1), 83-92.e1. doi:10.1016/j.jaad.2015.02.1112.

Landis, J., and Koch, G. (1977). An application of hierarchical kappa-type statistics in the assessment of majority agreement among multiple observers. Biometrics, 33(2), 363-374. doi:10.2307/2529786.

Matthews, A. G., Preston, H., Murray, A., and Hawkes, R.. (2018, October 1). Golf and skin health: A narrative review. Exercise Medicine, 2(13). doi:10.26644/em.2018.013. 
McWhirter, J.E., and Hoffman-Goetz, L. (2016). Application of the health belief model to U.S. magazine text and image coverage of skin cancer and recreational tanning (2000-2012). Journal of Health Communication, 21(4), 424-38.

doi:10.1080/10810730.2015.1095819.

McWhirter, J.E, and Hoffman-Goetz, L. (2015). Coverage of skin cancer and recreational tanning in North American magazines before and after the landmark 2006 international agency for research on cancer report. BMC Public Health, 15(1). 169. doi:10.1186/s12889-015-1511-1.

Noar, S.M., Gall Myrick, J., Zeitany, A., Kelley, D., Morales-Pico, B., and Thomas, N.E. (2015). Testing a social cognitive theory-based model of indoor tanning: Implications for skin cancer prevention messages. Health Communication, 30(2), 164-74. doi:10.1080/10410236.2014.974125.

Noar, S.M., Leas, E., Althouse, B.M., Dredze, M., Kelley, D., and Ayers, J.W. (2018). Can a selfie promote public engagement with skin cancer? Preventive Medicine, 111, 280-83. doi:10.1016/j.ypmed.2017.10.038.

Parsons, B.G., Gren, L.H., Simonsen, S.E., Harding, G., Grossman, D., and Wu, Y.P. (2018). Opportunities for skin cancer prevention education among individuals attending a community skin cancer screening in a high-risk catchment area. Journal of Community Health, 43(2), 212-19. doi:10.1007/s10900-017-0406-8.

Tang, L., and Park, S. (2017). Sun Exposure, Tanning Beds, and Herbs That Cure: An Examination of Skin Cancer on Pinterest. Health Communication, 32(10), 1192200. doi:10.1080/10410236.2016.1214223. 
U.S. Department of Health and Human Services. Surgeon General's call to action to prevent skin cancer. Washington, D.C.: U.S. Department of Health and Human Services, Office of the Surgeon General; 2014. Retrieved from hpps://www.surgeongeneral.gov on November 9, 2019. 